\title{
Transformative service-learning experience through participatory project management
}

\author{
Mark Anthony Abenir \\ Ateneo de Manila University, Philippines
}

\begin{abstract}
Studies have shown that for Service-Learning (SL) to be truly valuable and transformative, it must employ participatory project management practices and is ideally conducted in a face-to-face setting. This case study aims to highlight the strategies used to make SL projects long-term and participatory. It also measures the effectiveness of such approach in achieving a valuable and transformative SL experience for students and partner communities. Qualitative results show that students were able to develop desired personal, professional, and civic competencies. On the part of the partner communities, qualitative results reveal that they appreciate the year-long participatory SL engagement with the students that brought about high quality SL projects. Quantitative data, on the other hand, indicate that the paired samples t-test resulted in a moderate practical significant difference in the pre-and post-test scores of students when it came to their personal, professional, and civic mindedness skills. Finally, quantitative results indicate that partner communities reported that SL projects brought them a very favorable impact in terms of skills and competencies, motivation and commitments, personal growth and self-concept, and acquisition of knowledge.
\end{abstract}

\section{Keywords}

COVID-19 pandemic, participatory development, mixed methods, service-learning benefits.

Fecha de recepción: 24/XI/2021

Fecha de aceptación: 9/XII/2021

Abeniar, M.A. (2021). Transformative service-learning experience through participatory project management. RIDAS, Revista Iberoamericana de Aprendizaje Servicio, 12, 13-23.

DOI10.1344/RIDAS2021.12.3 


\section{El aprendizaje-servicio como experiencia transformadora a través de la gestión participativa de proyectos}

\section{Resumen}

La investigación ha demostrado que para que el aprendizaje-servicio (ApS) sea realmente valioso y transformador debe utilizar prácticas participativas de gestión de proyectos e, idealmente, realizarse en un entorno presencial. Este estudio de caso pretende poner de relieve las estrategias utilizadas para que los proyectos de ApS sean participativos y a largo plazo. También mide la eficacia de este enfoque para lograr una experiencia de ApS valiosa y transformadora para los estudiantes y los socios comunitarios. Los resultados cualitativos muestran que los estudiantes fueron capaces de desarrollar las competencias personales, profesionales y cívicas deseadas. Por parte de los socios comunitarios, los resultados cualitativos revelan que agradecen el compromiso participativo durante todo el año con los estudiantes que han dado lugar a proyectos de ApS de alta calidad. Los datos cuantitativos, por su parte, muestran una diferencia práctica moderada significativa en las puntuaciones previas y posteriores de los estudiantes cuando se trataba de sus habilidades personales, profesionales y de compromiso cívico. Por último, los resultados cuantitativos indican que los socios comunitarios manifiestan que los proyectos de ApS les aportaron un impacto muy favorable en términos de habilidades y competencias, motivación y compromisos, crecimiento personal y autoconcepto y adquisición de conocimientos.

\section{Palabras clave}

Pandemia, COVID-19, desarrollo participativo, método mixto, beneficios, aprendizajeservicio. 


\title{
L'aprenentatge servei com a experiència transformadora a través de la gestió participativa de projectes
}

\begin{abstract}
Resum
La investigació ha demostrat que perquè l'aprenentatge servei (ApS) sigui realment valuós i transformador ha d'emprar pràctiques participatives de gestió de projectes i, idealment, realitzar-se en un entorn presencial. Aquest estudi de cas pretén posar de relleu les estratègies utilitzades per fer que els projectes d'Aps siguin participatius i a llarg termini. També mesura l'eficàcia d'aquest enfocament per assolir una experiència d'ApS valuosa i transformadora per als estudiants i els socis comunitaris. Els resultats qualitatius mostren que els estudiants van ser capaços de desenvolupar les competències personals, professionals i cíviques desitjades. Per part dels socis comunitaris, els resultats qualitatius revelen que agraeixen el compromís participatiu durant tot l'any amb els estudiants que ha donat Iloc a projectes d'ApS d'alta qualitat. Les dades quantitatives, d'altra banda, mostren una diferència pràctica moderada significativa en les puntuacions prèvies i posteriors dels estudiants quan es tractava de les seves habilitats personals, professionals i de compromís cívic. Finalment, els resultats quantitatius indiquen que els socis comunitaris manifesten que els projectes d'ApS els van aportar un impacte molt favorable en termes d'habilitats i competències, motivació i compromisos, creixement personal i autoconcepte i adquisició de coneixements.
\end{abstract}

\section{Paraules clau}

Pandèmia, COVID-19, desenvolupament participatiu, mètode mixt, beneficis, aprenentatge servei. 


\section{Introduction}

Service-learning is an experiential, critical, and constructive learning pedagogy that intentionally integrates academic study with an organized service activity that addresses community needs, guided by reciprocal relations among students, faculty members, and partner communities, and systematic reflection on the service rendered by the students (Abenir \& Ma, 2020). A meta-analysis of studies on service-learning strongly suggest that students can greatly benefit in multiple ways from their involvement in servicelearning programs and that it validates the efforts of educators who make use of service-learning as a form of pedagogy (Yorio \& Ye, 2012). When it comes to communities, case studies have shown that service-learning often bring tangible economic and social benefits to them (Kindred, 2020; Lloyd et al., 2015), most especially on being able to access knowledge, skills, and human resources they need but could not afford, which is in the form of students and faculty members (McCollough, 2020). But Block and Bartkus (2019) found out that servicelearning is able to bring long-term value to partner communities when there are substantial time and resources allotted in the management of service-learning projects in terms of preparation, design, execution, and evaluation. Furthermore, Lara (2020) noted that for service-learning projects to be truly transformative, it must ensure the equal representation and participation of students, faculty

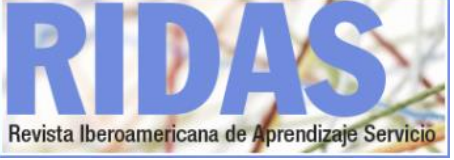

members, and partner communities in every step of the service-learning process. Thus, in summary, one can argue that for service-learning to be truly valuable and transformative, it must employ the use of participatory project management practices.

However, employing the use of participatory management practices in service-learning projects takes a longterm commitment, which is in contrast to service-learning projects which are often short-term and bounded within the timeframe set within the school curriculum (Butin, 2015). In addition, the underlying assumption here is that the participatory management of service-learning projects are done within a face-to-face (f2f) manner. This poses a seemingly insurmountable challenge since $f 2 f$ activities in Philippine schools have been suspended indefinitely as a response to the COVID-19 pandemic. Also, the transition to a fully online mode of education has prompted some higher educational institutions in the country to shorten the delivery of courses within a span of 8 weeks only, instead of the usual 16 weeks. This was done to minimize the risk of experiencing computer screen fatigue by the students. This is especially true in the Ateneo de Manila University (Ateneo), which is the setting of this study, where in the beginning of SY 2020-2021, all courses, including those designated as service-learning courses, were to be completed in 8 weeks and to be fully delivered online. Given these challenges, this study aims to highlight the strategies used to make servicelearning projects long-term and participatory. It also measures the 
effectiveness of such approach in achieving a valuable and transformative service-learning experience for students and partner communities.

\section{Methodology}

This case study is anchored on the theory of participatory development, which refers to an umbrella term for approaches that directly involve local people in the design and delivery of development initiatives, which could either be in the form of projects, programs, and partnerships (Eversole, 2015). The goal of participatory development is to ensure that attention is paid to maximizing benefits to local people while minimizing negative consequences by assessing the needs and views of affected local communities and attempting to build consensus about development project plans to be carried out with external agents (Tekman et al., 2012). In applying the theory of participatory development, the 40 third-year Development Studies (DS) students in the Ateneo who took service-learning courses during SY 2020-2021 serve as external agents who catalyze effective change by working in equal horizontal relationships with communities on the management of service-learning projects. To gauge the effectiveness of such approach, mixed methods with a convergent design was used to measure its impact on students and partner communities. This is done by merging quantitative and qualitative databases to compare or combine the results.

To measure the impact on students, quantitative data was gathered through the pre-test and post-test use of the Service-Learning Benefits (SELEB) scale answered by the students. The SELEB is a 32-item instrument that reliably measures the benefits of servicelearning (Cronbach's alpha range of 0.78 up to 0.84 ) using a 7 -point Likert scale ( 1 being not at all and 7 being very much) related to personal, interpersonal, professional, and civicmindedness growth of the students (Toncar et al., 2006). Out of the 40 DS students, 28 successfully answered the pre- and post-SELEB scale which was administered at the beginning and end of the SY. On the other hand, to measure the impact on partner communities, one key contact person from each of the five (5) partner communities were requested to answer the Community Impact Scale (CIS) at the end of the year-long servicelearning engagement. The CIS is a 46item instrument that reliably measures the impact of service-learning and other forms of university-community engagements (Cronbach's alpha range of 0.70 up to 0.94 ) using a 5 -point Likert scale ( 1 being strongly disagree and 5 being strongly agree) on partner communities in terms of their overall experience, social capital, skills and competencies, motivations and commitments, personal growth and self-concept, knowledge, organizational operations, and organizational resources (Srinivas et al., 2015).

Finally, to have an in-depth understanding of impact of the longterm and participatory management of service-learning projects on students, qualitative data was gathered through the submitted reflection papers of the

Abeniar, M.A. (2021). Transformative service-learning experience through participatory project management. RIDAS, Revista Iberoamericana de Aprendizaje Servicio, 12, 13-23. DOI10.1344/RIDAS2021.12.3 
students at the end of their year-long service-learning engagements. When it came to the partner communities, qualitative data was gathered by transcribing video-recorded verbal feedback, aside from collecting written feedback, given by partner communities during service-learning project presentations by the students conducted at the end of each course. Quantitative data gathered was analyzed using descriptive statistics and paired sample's t-test. On the other hand, qualitative data gathered was subjected to thematic analysis.

\section{Results and discussion}

\subsection{The Service-Learning Participatory Project Management Process}

The first semester of SY 2020-2021 in the Ateneo was divided into two quarters consisting of 8 weeks each. For the first quarter (Q1), the DS students took a community development course where they have been divided into 6 project management teams and the central focus of their service-learning engagement with their respective partner communities was to establish rapport, level-off expectations, and produce a comprehensive development assessment report (DAR). Everything was done remotely using varied online communication platforms such as Zoom, Google Meet, Facebook Messenger, and Slack to name a few. It is during Q1 that the student teams, with their respective partner communities, defined the needs, explored opportunities, analyzed the project environment, and designed alternatives for defining the service- learning project in relation to empowerment strategies they have learned in community development. For the second quarter (Q2), the DS students took a sustainable development course. It is during Q2 that the same student teams, together with their respective partner communities, remotely developed the overall parameters of their servicelearning project in relation to the sustainable development goals (SDGs), detailed the service-learning project implementation plan, communicated the service-learning project to target stakeholders, and established the service-learning project board, which is a final decision making body headed by the faculty handling the servicelearning courses and where key representatives from partner communities serve as board members. Finally for the second semester of the same SY, the DS students took a development project management course where the same students teams got to implement, monitor, and evaluate their respective servicelearning projects with their respective partner communities for the duration of 16 weeks. It is fortunate that during the second semester, the Ateneo allowed major courses, such as the development project management course, to run within a course of 16 weeks. The service-learning projects implemented, monitored, and evaluated during the second semester were the following:

1. AhonMulasaAlon (Rise from the Waves): An Online Social Advocacy Campaign and ThreePart Webinar Series for the 
benefit of COVID-19 related repatriated Overseas Filipino Workers all over the Philippines.

This was implemented by the DS students together with the Center for Migrant Advocacy, Philippines.

2. Barangay Talaibon Water Fund:

An Online Community Organizing

Campaign to establish a community-based Water Credit System for the benefit of relocatees affected by the explosion of the Taal Volcano in Barangay Talaibon, Batangas. This was implemented by the DS students together with Waves for Water, Philippines.

3. LupangAraw (Earth of the Sun): An Online Social Advocacy Campaign and whole day Online Webinar and Workshop on Organizational Development for the benefit of three (3) young farmer organizations in the Bicol and Panay Region of the Philippines. This was implemented by the DS students together with the PambansangKilusanngmgaSamah angMagsasaka (PAKISAMA).

4. Protect Our Lands: An Online Social Advocacy Campaign to Protect the Rights of Indigenous Peoples and Stop the Construction of the Kaliwa Dam in Infanta, Quezon. This was implemented by the DS students together with the Non-Tiber Forest Products-Exchange Program, Philippines.
5. Sama-sama Laban saPandemya (Collective Fight Against the Pandemic): An Online COVID-19 Awareness Campaign and FivePart Health Webinar Series for the benefit of Community Health Volunteers in GawadKalinga (GK) communities in Caloocan. This was implemented by the DS students together with GKCaloocan.

6. Tubig Para saPidpid (Water for Pidpid): An Online Social Advocacy Campaign regarding Water Inequality and MiniFundraiser to construct a gravityfed water system for the benefit of the Aeta indigenous community in SitioPidpid, Porac, Pampanga. This was implemented by the DS students together with Waves for Water, Philippines.

The 16-week course schedule under development project management provided the student teams enough breathing space to implement their projects with their partner communities, monitor their progress, and adjust to issues and risks that came along the way. To maintain the quality implementation of their respective service-learning projects, the student teams were required to produce a Mid-Term Evaluation Report, to evaluate service-learning project implementation midway so necessary changes can be made, and a Full Evaluation Report to measure the social impact of their respective servicelearning projects, as well as its impact to their learning. 


\subsection{Impact on Students}

The results of the paired samples t-test show that the DS students $(\mathrm{N}=28)$ reported to have a moderate practical significant difference in their pre-and post-test scores when it came to the growth of their personal (pre-test: $M=$ $5.75, \mathrm{SD}=1.23$; post-test: $M=6.39$, $\mathrm{SD}=0.47, \mathrm{t}(27)=-2.58, \mathrm{p}=0.02, \mathrm{~d}=$ 0.50 ), professional (pre-test: $M=5.92$, $S D=0.87$; post-test: $M=5.92, S D=$ $0.39, \mathrm{t}(27)=-3.23, \mathrm{p}=0.00, \mathrm{~d}=0.61)$, and civic-mindedness skills (pre-test: $M$ $=5.80, \mathrm{SD}=1.19$; post-test: $\mathrm{M}=$ 6.65, $\mathrm{SD}=0.36, \mathrm{t}(27)=-3.81, \mathrm{p}=$ $0.00, d=0.72$ ). There was no significant difference when it came to the growth of their interpersonal skills. Nevertheless, it must be noted that their interpersonal skills remained high before $(M=6.21, S D=0.80)$ and after $(M=6.44, S D=0.37)$ their year-long service-learning engagement.

Qualitative results complement the quantitative findings, as students reveal in their reflections that they were able to hone their self-management skills and truly practice the science and art of managing development projects. Also, through the sustained year-long and participatory service-learning engagement, the students claimed that they were given the opportunity to better know their partner communities, which helped them to empathize and care more for their advocacies and social concerns. This in turn has prompted them to deliver high quality work and service. As one of the students noted in her reflection:

- $\quad$ "I realized that strong development projects can be executed even during difficult times. Thus, I should not let seemingly large obstacles stop me from trying to make a positive impact on the world. Further...I realized that real change does not usually happen from just one individual but rather a group of individuals working together to make positive change in the world. Lastly, in realizing that, through the feedback from the partner community, I can make a positive impact on the world, thus, I became even more motivated to continue making these positive impacts. I will always remember this experience as the first long-term project where I realized my potential as a change maker. Ultimately... this is my first major step into becoming a socially responsible citizen of the world" (Reflection of a DS student).

However, qualitative results also reveal students unanimously felt that the reliance on remote and virtual engagements has brought them anxiety, feelings of uncertainty, and ultimately, exhaustion. This is due to sporadic internet connectivity problems and issues on access to communication devices which made it a struggle for both students and partner communities to effectively communicate with each other and exchange timely information. Thus, students yearn for the return of f2f engagement where they feel they could be more effective in working together with their partner communities and effectively communicate with their team members. This might explain why 
there is no significant difference in the students' interpersonal development and only a moderate practical significance difference in terms of their growth in their personal, professional, and civic-mindedness skills.

\subsection{Impact on Partner Communities}

Descriptive analysis of the results of the CIS reveal that the partner communities, through their key contact persons $(\mathrm{N}=5)$, reported that the yearlong service-learning engagement they had with the DS students created an overall very positive experience on their part $(M=4.89, S D=0.30)$.

Specifically, the service-learning projects that they have worked together with the DS students brought very favorable impact in their respective community organizations in terms of acquired skills and competencies $(M=4.60, S D=0.67)$, motivation and commitments ( $M=$ $4.73, \mathrm{SD}=0.38)$, personal growth and self-concept $(M=4.60, S D=0.49)$, and acquisition of knowledge $(\mathrm{M}=$ $4.56, S D=0.64)$. On the other hand, they also reported that the servicelearning projects brought favorable impact in terms of social capital ( $M=$ 4.33, SD $=0.42)$, organizational operations $(M=4.32, S D=0.63)$, and organizational resources $(M=3.90, S D$ $=0.82$ ). However, it must be noted that impact on organizational resources received the lowest score when compared to the rest. Further, qualitative results strengthen quantitative findings, as partner communities claim that the year-long service-learning engagement with the DS students yielded better servicelearning project results, when compared to other short-term servicelearning projects they have worked with other service-learning courses in the Ateneo. As one of the partner communities commented:

- "Our organization would like to extend our profuse gratitude for this fruitful and engaging partnership. Commendable work of the students, formators, and faculty members involved. This year-long setup is ideal for such partnerships. I recommend consideration of such long-term partnership with other classes or courses in the Ateneo that have similar or related designs" (Feedback from a key contact person from a partner community).

In addition, they realized that aside from being mentors to the students, they also felt learning together with the students the processes involved in participatory project management.

\section{Conclusions}

The year-long service-learning engagement of the students, following the participatory management of service-learning projects, generally became a transformative experience for the students. However, purely remote and virtual engagements, coupled with technological limitations, served as barriers to foster deeper connection among students themselves and with their partner communities. On the other hand, partner communities reported that they had an overall positive experience in their one-year servicelearning engagement with the students, 
and they benefited much from the participatory project management practices employed. Thus, it can be said that in spite of the limitations imposed by the online set-up, the year-long engagement that employs the use of participatory project management practices, through the alignment of 3 online courses across 2 semesters, has resulted in a valuable and transformative service-learning experiences for students and partner communities.

\section{References}

Abenir, M. A. D., \& Ma, C. H. K. (2020). Social Theories and Service Learning: Towards Building an Integrated ServiceLearning Sociological Framework. Journal of Community Engagement and Higher Education, 12(3), 53-68.

Block, E. S., \& Bartkus, V. O. (2019). Learning to Serve: Delivering Partner Value Through Service-Learning Projects. Academy of Management Learning \& Education, 18(3), 361-387. https://doi.org/10.5465/amle.2016.027 $\underline{8}$

Butin, D. W. (2015). Dreaming of Justice: Critical Service-Learning and the Need to Wake Up. Theory Into Practice, 54(1), 5-10.

Eversole, R. (2015). Knowledge Partnering for Community Development. Routledge.

Kindred, J. (2020). Nonprofit Partners' Perceptions of Organizational and Community Impact Based on a LongTerm Academic Service-Learning Partnership. Journal of Community
Engagement \& Scholarship, 13(1), 114.

Lara, J. J. (2020). Problem-Based solutions from the classroom to the Community: Transformative approaches to mitigate the impacts of boom-andbust in declining urban communities. Land Use Policy, 93, 104094. https://doi.org/10.1016/j.landusepol.20 19.104094

Lloyd, K., Clark, L., Hammersley, L., Baker, M., Rawlings-Sanaei, F., \& D'ath, E. (2015). Unintended Outcomes of University-Community Partnerships: Building Organizational Capacity with PACE International Partners. AsiaPacific Journal of Cooperative Education, 16(3), 163-173.

McCollough, C. J. (2020). Selling St. EOM's Pasaquan: Service-Learning's Impact on Economic, Civic, and Cultural Life. Journal of Higher Education Outreach \& Engagement, 24(3), 87103.

Srinivas, T., Meenan, C. E., Drogin, E., \& DePrince, A. P. (2015). Development of the Community Impact Scale Measuring Community Organization Perceptions of Partnership Benefits and Costs.

Michigan Journal of Community Service Learning, 21(2), 5-21.

Tekman, E. D., Hassapi, A., Chrysostomou, G., Konnaris, Y., Neophytou, H., Yılmaz, S. L., \& Tekman, T. (2012). Participatory Development Training Manual. Cyprus: Technical Chamber of Cyprus, UNDP, USAID, Peace it Together \& KTMMOB.

Toncar, M. F., Reid, J. S., Burns, D. J., 
Anderson, C. E., \& Nguyen, H. P. (2006). Uniform Assessment of the Benefits of Service Learning: The Development, Evaluation, and Implementation of the Seleb Scale. Journal of Marketing Theory and Practice, 14(3), 223-238.

https://doi.org/10.2753/MTP1069$\underline{6679140304}$

Yorio, P. L., \& Ye, F. (2012). A MetaAnalysis on the Effects of ServiceLearning on the Social, Personal, and Cognitive Outcomes of Learning. Academy of Management Learning \& Education, 11(1), 9-27.

https://doi.org/10.5465/amle.2010.007 $\underline{2}$ 